\title{
Observation of Humpback Whales (Megaptera novaeangliae) in the Waters Adjacent to the Chukotka Peninsula with Comparisons to Historical Sighting Data
}

\author{
Vladimir V. Melnikov \\ V.I. Il'ichev Pacific Oceanological Institute, Far East Branch, Russian Academy of Science, Vladivostok, Russia \\ Email: 4vlmelnikov8@gmail.com
}

How to cite this paper: Melnikov, V.V. (2019) Observation of Humpback Whales (Megaptera novaeangliae) in the Waters Adjacent to the Chukotka Peninsula with Comparisons to Historical Sighting Data. Open Access Library Journal, 6: e5407.

https://doi.org/10.4236/oalib.1105407

Received: April 16, 2019

Accepted: May 17, 2019

Published: May 20, 2019

Copyright $\odot 2019$ by author(s) and Open Access Library Inc.

This work is licensed under the Creative Commons Attribution International License (CC BY 4.0).

http://creativecommons.org/licenses/by/4.0/

\begin{abstract}
This paper presents data from shore-based and limited boat observations of the seasonal distributions of humpback whales in waters adjacent to the Chukotka Peninsula from 1994 and 2012. Under favourable ice conditions, humpback whales were spotted off the coast of the Chukotka Peninsula as early as the end of May. During the summer, humpback whales remained dispersed in the coastal waters of the Chukotka Peninsula alone and in pairs. In the fall, humpback whales formed aggregations in the extreme southern Chukchi Sea, and northern Gulf of Anadyr. The whales moved away from the observation area before freeze-up. The waters of this area have historically been-and still remain-the summer grazing grounds of humpback whales. The increased number of humpback whales sighted here is an indication of the population increasing, signalling a restoration of their numbers in the waters off the Chukotka Peninsula and a recovery of the stock of humpback whales in the North Pacific.
\end{abstract}

\section{Subject Areas}

Marine Biology

\section{Keywords}

Humpback Whales, Seasonal Distributions, Waters Adjacent to the Chukotka Peninsula, Bering Sea, Chukchi Sea, Seniavin Strait, Gulf of Anadyr, Summer Grazing Grounds

\section{Introduction}

Humpback whales are widely distributed in the coastal zones of the northern 
Pacific. The first information about the presence of humpback whales near Chukotka in the summer months comes from information supplied by the "Aleut" whaling flotilla that operated in these waters in the 1930s and early 1940s. In the pre-World War II and war periods, Chukotka waters were one of the main areas of the humpback fishery. In the 1930s and early 1940s, the number of humpback whales in the Chukchi Sea was quite high. For example, in 1934, the flotilla counted 270 humpback whales sighted from the whaler "Trudfront", 123 whales from the "Avangard" and 112 whales from the "Entuziast" [1]. In July and September 1937, 90 humpback whales were counted from the shore of the Bering Strait and 253 humpbacks from shore on Cape Serdse-Kamen. In August and September 1939, 25 whales were sighted in the Bering Strait [2]. From the first through seventh of September 1939, 100 humpback whales were sighted between the Bering Strait and Cape Serdse-Kamen [3].

By the beginning of the 1940s, the number of these whales decreased. In 1942, observers on the "Aleut" flotilla saw 33 humpback whales in 17 days and harvested three of them [4]. Between 28 August and 12 September 1948, on a course going between the Bering Strait and Cape Schmidt, 20 humpback whales were seen [3]. During research expeditions in the Chukchi Sea in the late 1950s and early 1960s, only individual whales and small groups were sighted in the area around Cape Serdse-Kamen [5], and single isolated whales were spotted off Cape Vankarem. Thus, since the initiation of commercial humpback whale hunting in the 1930s, their numbers in the Chukchi Sea gradually diminished. From 24 August to 8 September 1964, the whaling flotilla "Dalniy Vostok" (Far East) in the north-eastern part of the Gulf of Anadyr produced 68 humpback whales [6]. Later, their numbers in the waters adjacent to the Chukotka Peninsula were so low that the whales did not represent a commercial interest.

The end of whaling decreased the interest in studying humpback whales. Long-term information of humpback whales in Russian waters came along with works on other species of marine mammals.

However, starting in 1990, together with Chukotka Native residents (Eskimo and Chukchi), we carried out shore-based observations of marine mammals from the capes and points dotting the Chukotka Peninsula. This work-together with data on other marine mammals-provided us with information about humpback whales in the waters off the Chukotka Peninsula.

The primary purpose of the current study was to examine the seasonal movements and relative abundance of humpback whales in the coastal waters surrounding the Chukotka Peninsula. This study is based on observations of marine mammals from shore-based observation posts and boats between 1994 and 2012.

\section{Materials and Methods}

The observation of humpback whales was conducted concurrently with the observation of other marine mammal species. Table 1 demonstrates, in some years, up to 30 Native Chukotkan observers were employed to help. Only one or two 
Table 1. Timing and numbers of humpback whales observations in the coastal waters of the Chukotka Peninsula.

\begin{tabular}{ccccc}
\hline Years & Number of observers & Start date & End date & Number of observations \\
\hline 1993 & 5 & May 5 & November 30 & 338 \\
1994 & 26 & February 1 & December 27 & 2616 \\
1995 & 28 & February 1 & December 27 & 4089 \\
1996 & 30 & January 1 & December 20 & 3596 \\
1998 & 9 & April 1 & December 30 & 834 \\
1999 & 19 & April 1 & November 30 & 1786 \\
2000 & 20 & January 10 & December 30 & 2290 \\
2002 & 29 & March 1 & November 30 & 3223 \\
2003 & 29 & March 1 & November 28 & 2872 \\
2004 & 9 & April 1 & December 28 & 776 \\
2005 & 20 & April 1 & November 30 & 1704 \\
2010 & 2 & January 11 & November 29 & 492 \\
2011 & 3 & January 11 & December 30 & 596 \\
2012 & 2 & May 3 & December 4 & 224 \\
\hline
\end{tabular}

observers were involved from the beginning through the end of the work. Some watched from observation posts in Native villages on shore, while others counted from motorboats during hunting trips to obtain marine mammals for food and other needs. Observations were conducted mainly from April through November, but some were conducted all year round.

Visual observations were made with binoculars, with the observers taking note of the elevation of the observation perch, duration of observations, observation conditions (direction and force of wind, visibility, presence or absence of whitecaps), percentage of ice cover, number of marine mammals sighted, approximate distance from shore and swim direction. Of the sighting data associated with each count, we used only swim direction and percentage of ice cover. Both variables were assessed subjectively by the observers.

In the course of the observations, the hunters employed gained experience in observing. Organisation also improved as work progressed. Table 1 demonstrate the most extensive research efforts occurred from 1994-1996 and then in 2000, 2002, 2003 and 2005. The relative lack of data collected in 1993 was because of the lack of experience of the observers, while poor organisation was responsible for the lack of data in 1997 and scant information for 1998.

Recording the length of time an observer conducted observations on any particular day turned out to be a difficult organisational issue. It would take only 30 minutes of actual observation time to determine the number of animals and what species they were. Yet most of the observers working in the villages listed the duration of observations as the length of the working day, which obviously 
bore little relation to the time spent observing because the observations were conducted sporadically. But it must also be kept in mind that a hunter's own observations are always augmented by information received from other people in the village who are looking out to sea. For these reasons, the observers found it hard to decide on an observation time, with some recording the time spent looking through binoculars, with others noting the time spent on the shore and still others giving the length of the working day. Observers sitting in a boat during a hunting expedition may have been hampered by a low vantage point, limiting their field of vision, but on the other hand, they were constantly on the move, and all members of the crew watched out for marine mammals, often from dawn till dark. Information, however, was recorded in a logbook only at the end of the working day and was always integrated; the observers usually put the length of time they spent at sea as their observation time, which could often be as long as 18 hours. But even during hunting trips, observations were not conducted constantly throughout the day because the observers were interrupted by actual hunting activity and the work connected with getting the harvested animals back to shore. For all these reasons, we considered each count from one observer day as an observation, without regarding the duration or intensity of the search. Therefore, our fundamental unit for analysis was the number of whales per observation. During the analysis, data were normalised to the unit (number of whales/number of observations) to provide an average for a village, region or period of time. Because most villages in neighbouring areas had several observers working independently of one another, we averaged the data from all the observers working in one area.

Figure 1 shows, because of spatial differences in the conditions, the analysis was carried out in the three areas from south to north, as follows:

1) Gulf of Anadyr: The coastal waters of the southern Chukotka Peninsula, including the northern part of the Gulf of Anadyr;

2) Bering Sea: The coastal waters off eastern Chukotka Peninsula, including the extreme north-western waters of the Bering Sea adjacent to the Bering Strait; and

3) Chukchi Sea: The coastal waters of the northern Chukotka Peninsula, including the south-western waters of the Chukchi Sea.

\section{Results}

\subsection{Spring and Early Summer (April-July) Distribution}

\subsubsection{Gulf of Anadyr}

As shows Figure 2 and Figure 3, the first humpback whales appeared in the north-western part of the Gulf of Anadyr in the second ten day period of June with the melting of the last ice. The earliest arrival of humpback whales was recorded on 2 June 2010 around Cape Yakun (observation post Sireniki) in the north-eastern part of the Gulf of Anadyr. Single humpback whales were seen here during June in 1994, 2002, 2009, 2010 and 2011. In the cold late spring of 
1994, the first humpback whale was sighted on June 10 near Enmelen in the northern part of the Gulf of Anadyr.

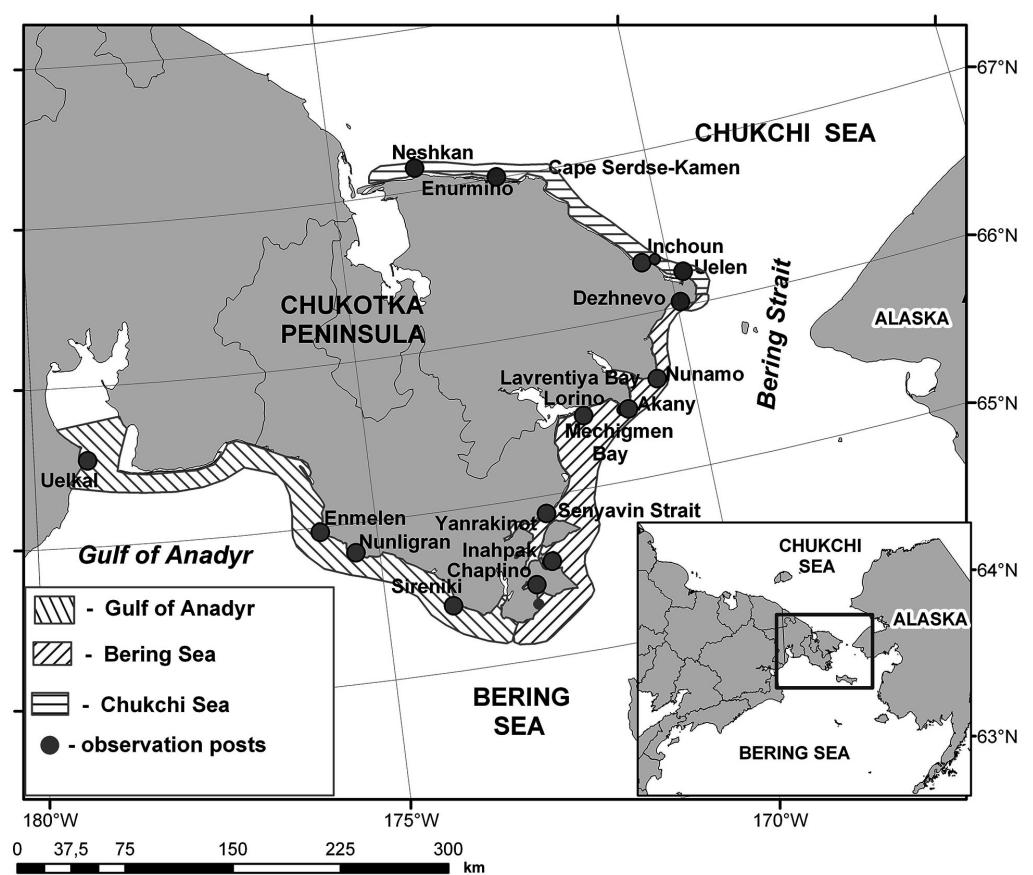

Figure 1. Study area. Locations of observation posts along the Chukotka coast from which humpback whales were observed.

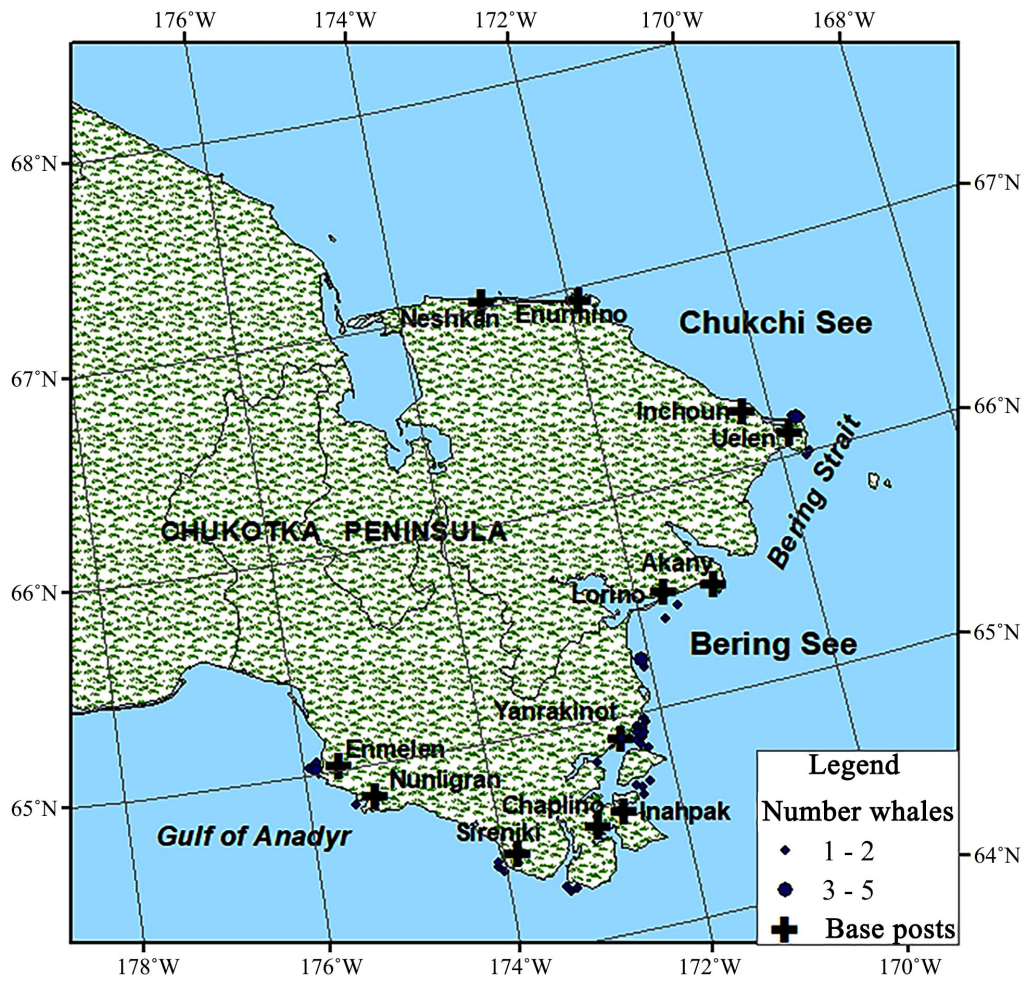

Figure 2. Spring distribution of humpback whales in the waters adjacent to the Chukotka Peninsula for all the studied years. 
1998

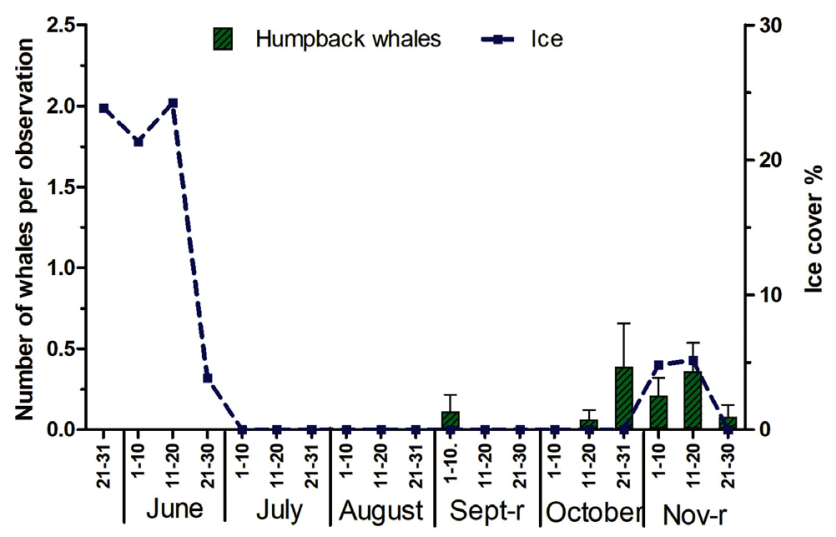

2003

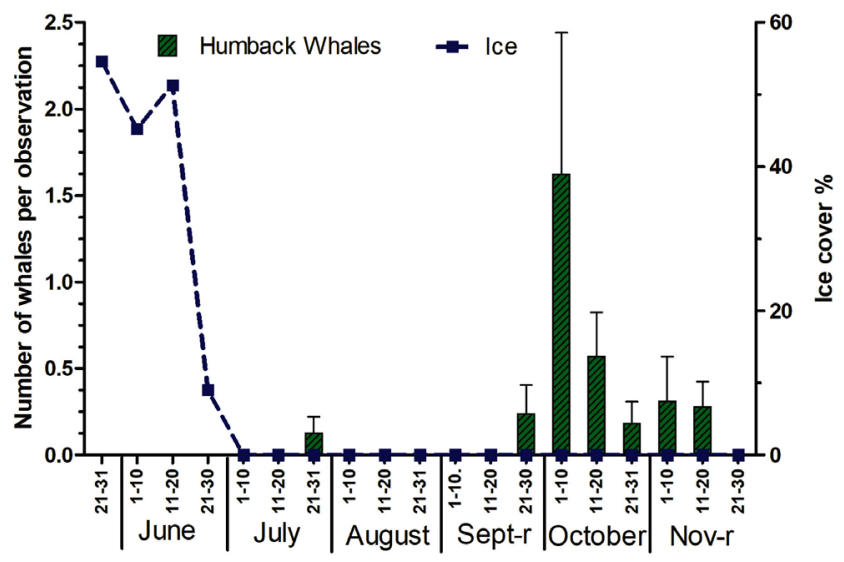

All Years

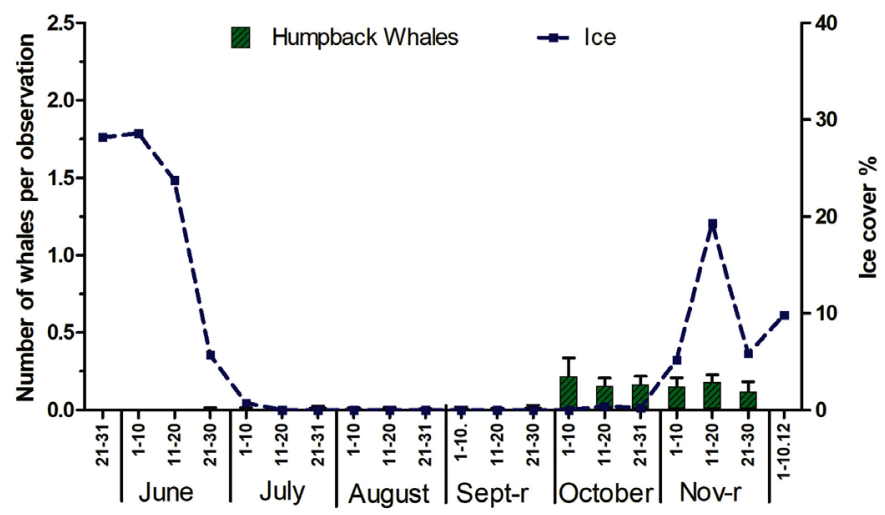

Figure. 3. Relative numbers of humpback whales observed in the southern coastal waters off the Chukotka Peninsula (Gulf of Anadyr) in 1998 with late melting and early formation of ice and in 2002 with late melting and late formation of ice. The bottom panel shows the averaged data for all the studied years.

\subsubsection{Bering Sea}

As shows Figure 2 and Figure 4, when ice conditions are favourable, humpback whales begin to approach Bering Sea waters off the Chukotka Peninsula as early as the middle of May. Whales were noted in polynyas beyond shore-fast ice when the ice cover decreased to $70 \%-80 \%$. The earliest a humpback whale was 
sighted there on April 281996 in the area around Cape Chukotski. In May 1996, 2000 and 2005, humpback whales were sighted in the northern part of Strait Senyavin and Mechigmen Bay from observation posts Janrakinnot and Lorino. The humpback whales moved among the broken ice that covered $60 \%-80 \%$ of the water surface. In June 1995, 1996, 2000, 2003 and 2005, the singles, pairs and groups of up to five humpbacks appeared along the entire east coast of the Chukotka Peninsula.

2000

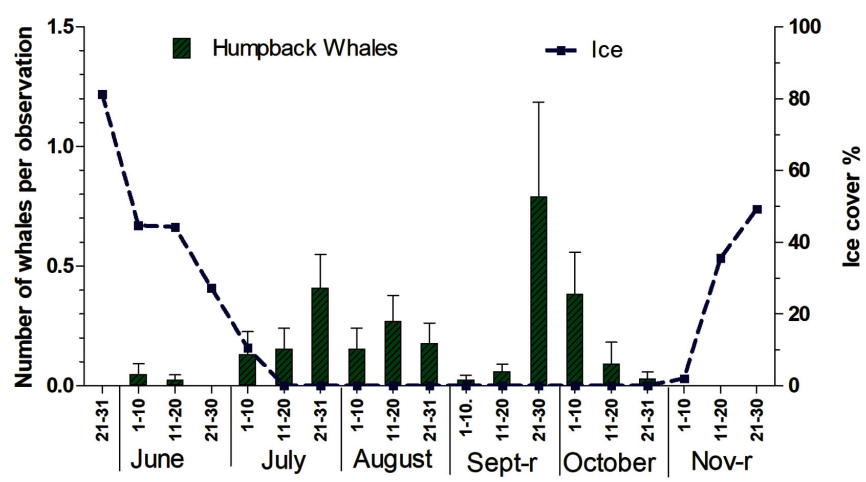

2003

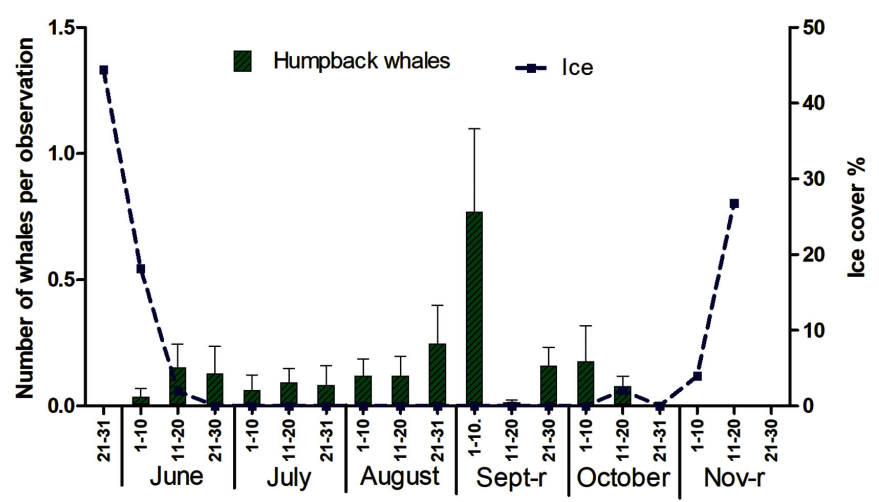

All Years

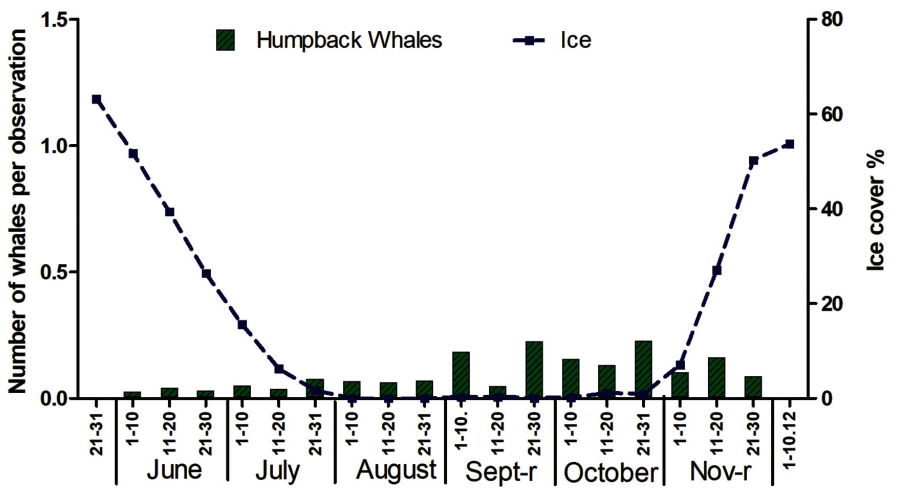

Figure 4. Relative numbers of humpback whales observed in the eastern coastal waters off the Chukotka Peninsula (Bering Sea) in 2000 with late melting and in 2003 with early melting of ice. The bottom panel shows the averaged data for all the studied years. 


\subsubsection{Chukchi Sea}

The earliest entry of two single humpback whales in the south-western part of the Bering Strait was registered on June 3, 2000 in the Cape Peak area. In the Chukchi Sea, the first humpback whales (mother with baby) were seen on June 262005 near the north-western entrance to the Bering Strait (observation post Uelen). Here, on June 27 2010, a group of three individuals were by the shore. According to the observer, the whales appeared to be fed.

\subsection{Summer and Early Autumn (July-September) Distribution}

\subsubsection{Gulf of Anadyr}

As shows Figure 4 and Figure 5 in July to September, no sizeable aggregations of humpback whales were seen in the northern part of the Gulf of Anadyr. Only on July 152011 was a group of 16 humpback whales registered in the area around observation post Nunligran. But singles, couples and triplets of humpback whales met annually during the summer throughout the entire southern coast of the Chukotka Peninsula.

\subsubsection{Bering Sea}

In the summer, humpback whales were observed annually along the entire eastern coast of the Chukotka Peninsula. Most often, they were sighted at the Senyavin Strait. As shows Figure 5, singles, couples and small groups of up to six individuals were seen at the northern entrance of the straight and directly in the strait. These whales swam at a distance of $1-3 \mathrm{~km}$ from shore mostly alone or in

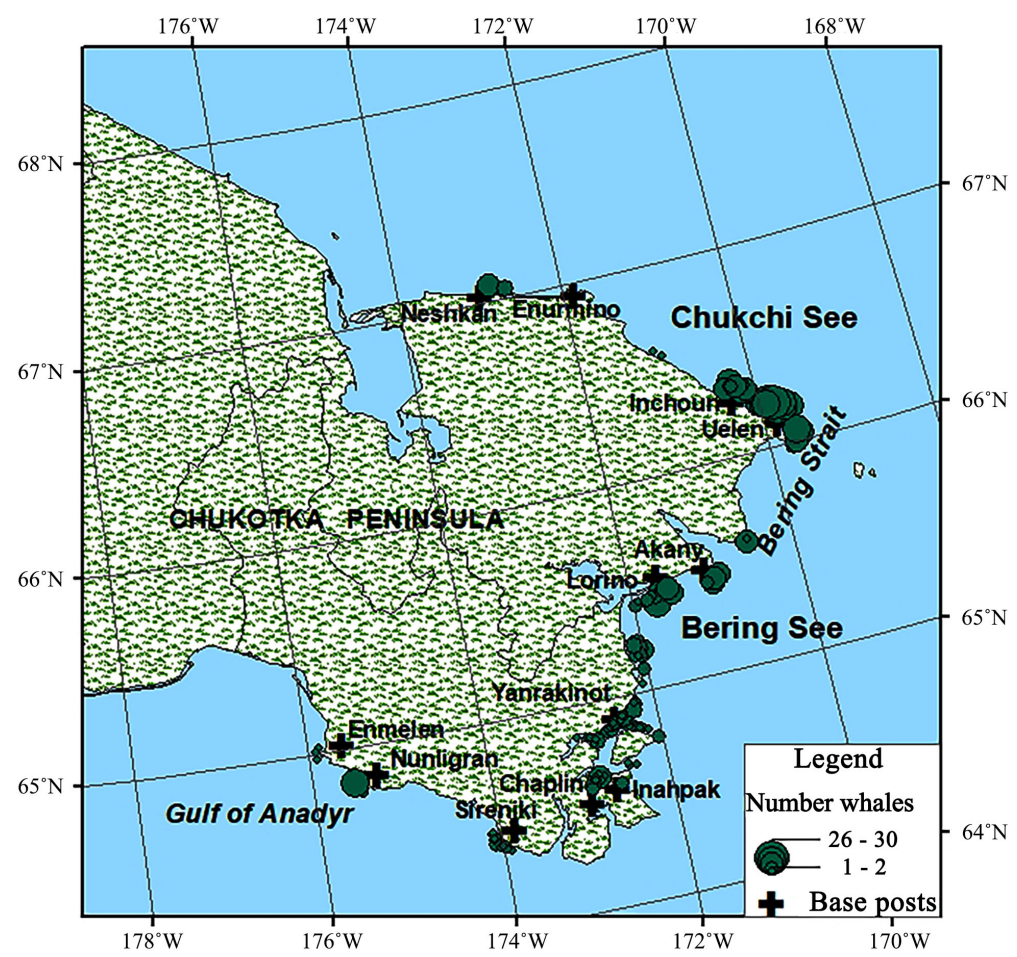

Figure 5. Summer and early autumn (July-September) observers sighting of humpback whales in the waters adjacent to the Chukotka Peninsula for all the studied years. 
pairs. As a rule, the humpback whales moved along the shore. Observers repeatedly reported that in the Senyavin Strait, the humpbacks were feeding (making circles under the water). From August-September 2000, 2003 and 2012, groups of up to 25 individuals were registered by the observers in Mechigmen Bay and in the south-western part of the Bering Strait.

\subsubsection{Chukchi Sea}

Figure 5 and Figure 6 shows, in the northern coastal waters of Chukotka Peninsula during the summer feeding season, humpback whale observers saw whales annually. The whales appeared in the Chukchi Sea, mostly in July after the breakup of the shore-fast ice. Throughout July, humpbacks were often sighted off Cape Inchoun and Cape Uelen singly and in pairs, sometimes in groups of up to eight individuals both inshore and at a distance of up to $15 \mathrm{~km}$ offshore. Starting in mid-August, their relative numbers would increase. In August and September, humpback whales were spotted primarily in the same area off Capes Uelen and Inchoun. However, their numbers increased significantly over the observed period, especially in 2011 and 2012, when in the vicinity of the Uelen, observers sighted an aggregation of up to 40 humpback whales. In the cold years $(1994,1998)$ when the ice did not leave the coastal waters of the western part of the Chukchi Sea in the summer, the humpback whales fattened among the broken ice, which had a cover of up to $40 \%$. For the entire observation period, only twice on August 222003 a group of 6 and on July 252012 a group of 3 whales were seen in the western part of the Chukchi Sea near Neschakan village.

\subsection{Autumn (October-November) Humpback Whale Distribution}

During autumn, humpback whales disperse from the Chukchi Sea into the Bering Sea. We therefore discuss the three areas in reverse order.

\subsubsection{Chukchi Sea}

In the typical years during autumn, the humpbacks left the Chukchi Sea when the first ice appeared, right around when the ice cover reached $20 \%-30 \%$. In the warm years, when the ice came only in late November and early December, the last humpback whales in the Chukchi Sea were seen 1.5 months before the appearance of ice. As shows Figure 7, in years when freeze-up occurs early, the humpback whales apparently moved out of the Chukchi Sea as early as the beginning of October. This was the case in 1994 when (October 1-3 1994) the last three groups of humpback whales of up to 15 individuals passed by Cape Uelen heading toward the Bering Strait.

When the ice set in late, the presence of humpback whales in the Chukchi Sea was appreciably greater. Humpback whales were found in particularly large numbers off the extreme north-eastern coast of the Chukotka Peninsula. In the north-western part of the Bering Strait, humpback whales were seen passing by in groups of two and three, both close inshore and at a distance of up to $15 \mathrm{~km}$ offshore. In October 1994, 2010, 2011 and 2012, aggregations of up to 50 hump- 
back whales were sighted off Cape Uelen, moving toward Bering Strait. At the same time, the observers pointed out that there were more whales because accounting difficult due to bad weather and long distance to whales. The latest entry of humpback whales into the Bering Strait was registered on 11 November 2010. A noteworthy fact is that at the north-western entrance to the Bering Strait, the number of whale groups sighted, as well as the number of individuals in each group, would increase appreciably every autumn compared with the other seasons. It is possible that these increasing numbers may be linked to the formation of aggregations prior to the start of the autumn migration.
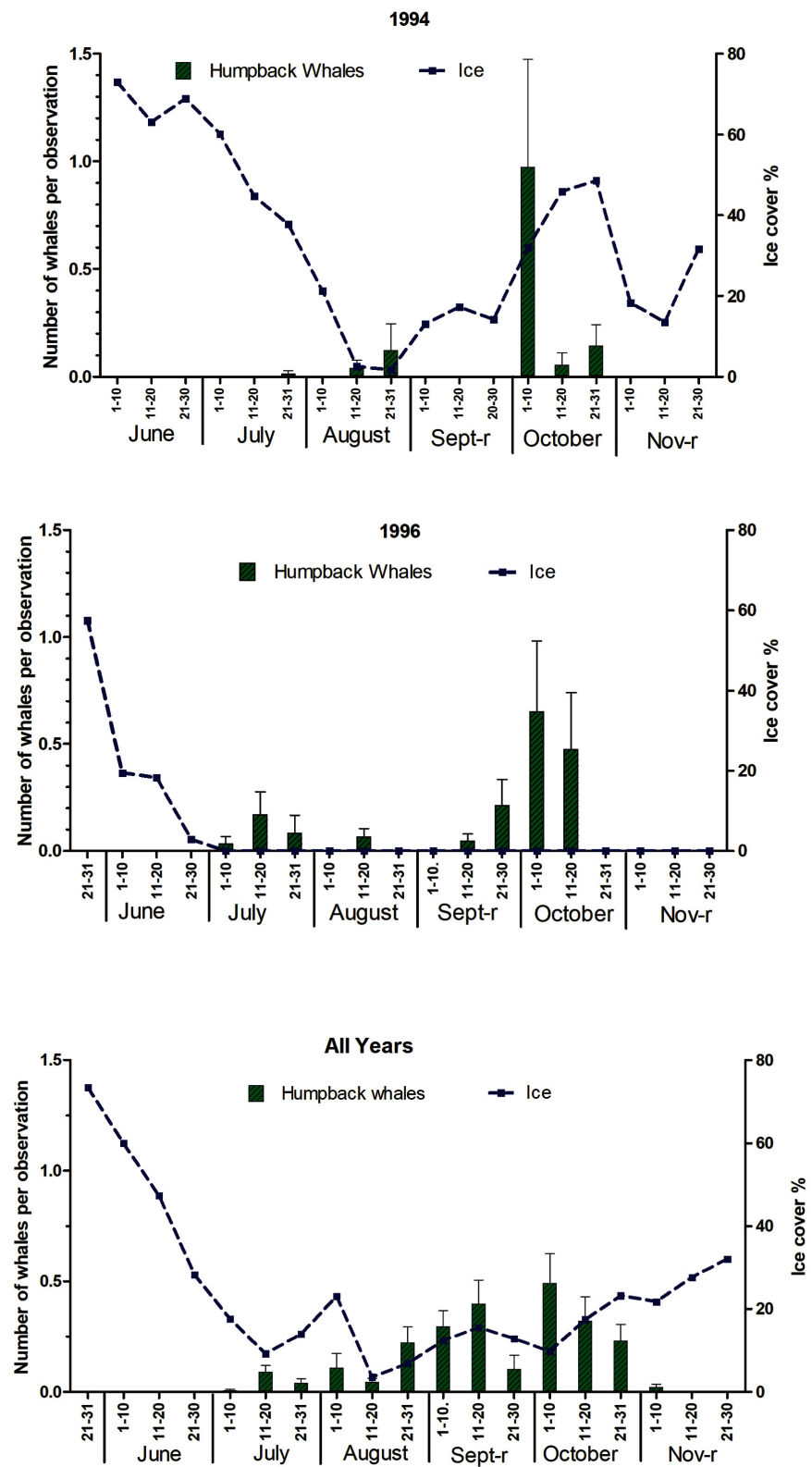

Figure 6. Numbers of humpback whales observed in the northern coastal waters off the Chukotka Peninsula (Chukchi Sea) in 1994 with late melting and early formation of ice and in 2002 with late melting and late formation of ice. The bottom panel shows the averaged data for all the studied years. 


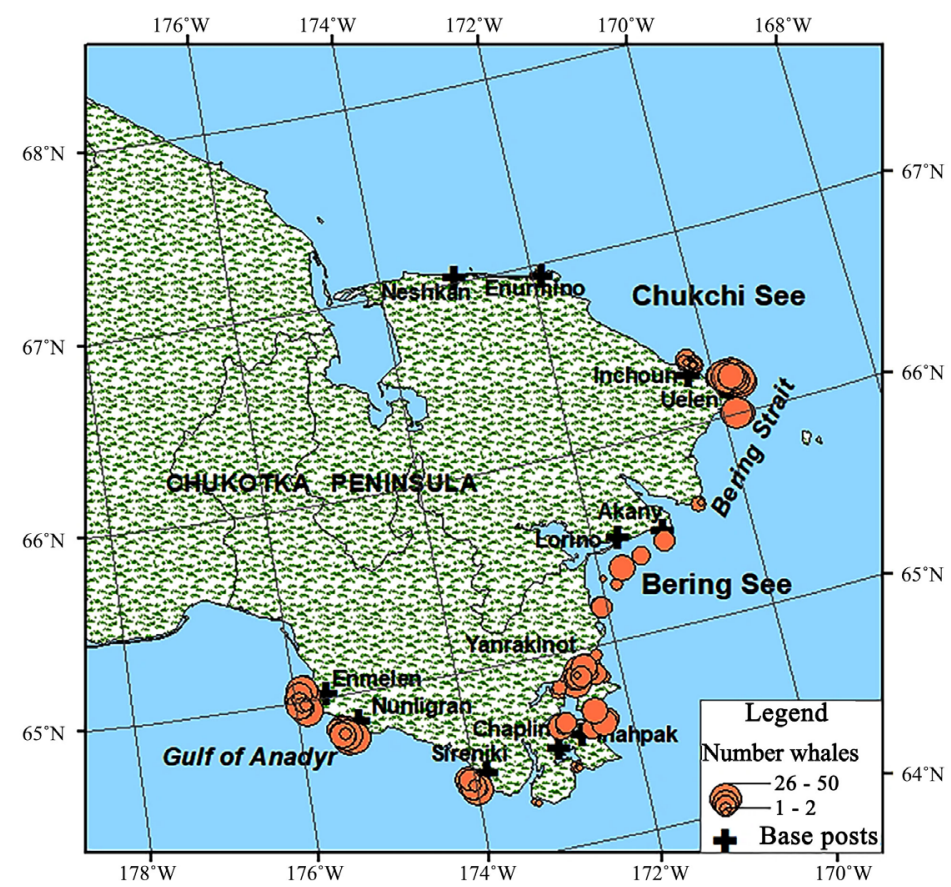

Figure 7. Autumn (October-November) observer sightings of humpback whales in the waters adjacent to the Chukotka Peninsula for all the studied years.

\subsubsection{Bering Sea}

In October-November, in the Bering Sea, as shows Figure 7, humpback whales stayed predominantly inside the Senyavin Strait's northern entrance. Observers annually recorded these whales in the strait singly and in small groups of up to 10 individuals dispersed throughout the strait. Sometimes, in the middle and end of October, large groups of humpbacks, with up to 50 individuals, passed into the strait, moving south. An aggregation of humpback whales of up to 30 individuals was recorded at the end of October 1996 near Cape Peak and south of it. In addition, pairs and single humpback whales were seen off Cape Akany, Kinkay Island, Tkachen bay and Cape Chukotsky. By autumn, as in the Chukchi Sea, the number of humpback whales in the Bering Sea was significantly increasing. The average values of October, for all the studied years, exceed the average values of August by 5.6 times.

In early November, the number of humpbacks in these waters began to decline gradually. By the end of the month, these animals were not seen near the eastern coast of Chukotka. The latest date of registration of a humpback whale was on November 23, 1995 in the northern part of the Senyavin Strait. Both from the Chukchi Sea and from the eastern coast of Chukotka, in the cold years, the last humpback whales left when the first ice appeared and in warm years left before the beginning of ice formation.

\subsubsection{Gulf of Anadyr}

In the northern part of the Gulf of Anadyr in early October, the number of humpback whales markedly increased. In October of every studied year, single, pair and small groups of up to six humpback whales were recorded all along the 
entire southern coast of the Chukotka Peninsula. At the end of October 2010 and 2011 in the area of Cape Achchen (settlement Nunligran), humpbacks formed congregations of 30 - 50 individuals. In 2011, in the Achchen area, humpback aggregations were held until the end of November. In the area of Sireniki village in November 1995 and then in October-November 2002-2011 every year, observers saw humpbacks entering the northern part of the Gulf of Anadyr, both singly and in small groups. The most numerous whales in the northern part of the Gulf of Anadyr were noted in the second half of November before the formation of ice. So on November 11 and 12 2004, observers registered whales passing to the northern part of the Anadyr Gulf in groups of 42 and 20, respectively, and on November 5 and 12 2011, observers saw 21 and 12 individuals, respectively. The last humpback whales were seen in early December. The latest registration is December 42004 in the area around Sireniki.

\subsection{Interannual Changes}

Figure 8 shows, the number of humpback whales feeding during the summer period in the coastal waters off the Chukotka Peninsula varied interannually.

In the northern part of the Gulf of Anadyr until 2003, the number of humpback whales appearing during the feeding season was relatively small. Figure 9 shows before 2002, their relative abundance in the southern coastal region of Chukotka varied from $0.01-0.03$ individuals per observation. Since 2003, an increase in their relative numbers was noted in this region. In more recent years, the number of humpback whales increased to 0.31 in 2010 and 0.9 in 2011. This is 30 and 90 times more than in 1994-2002.

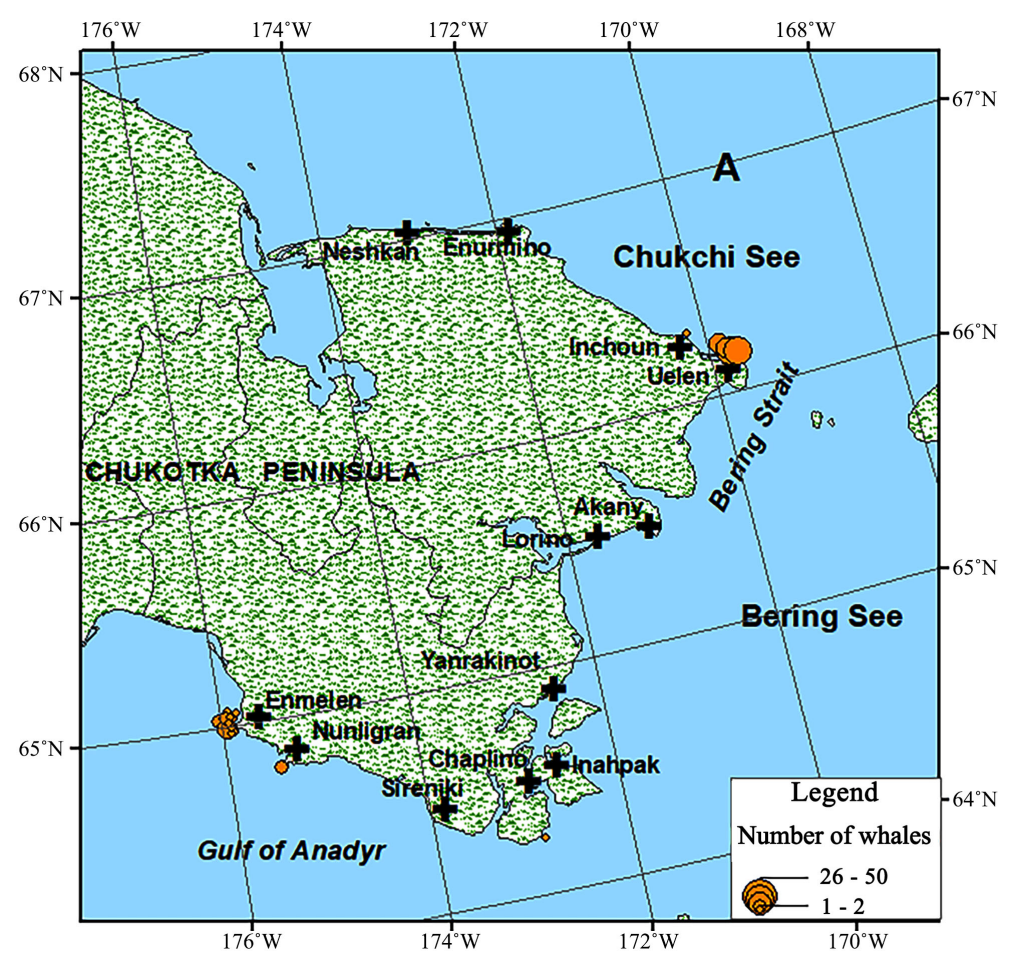

(a) 


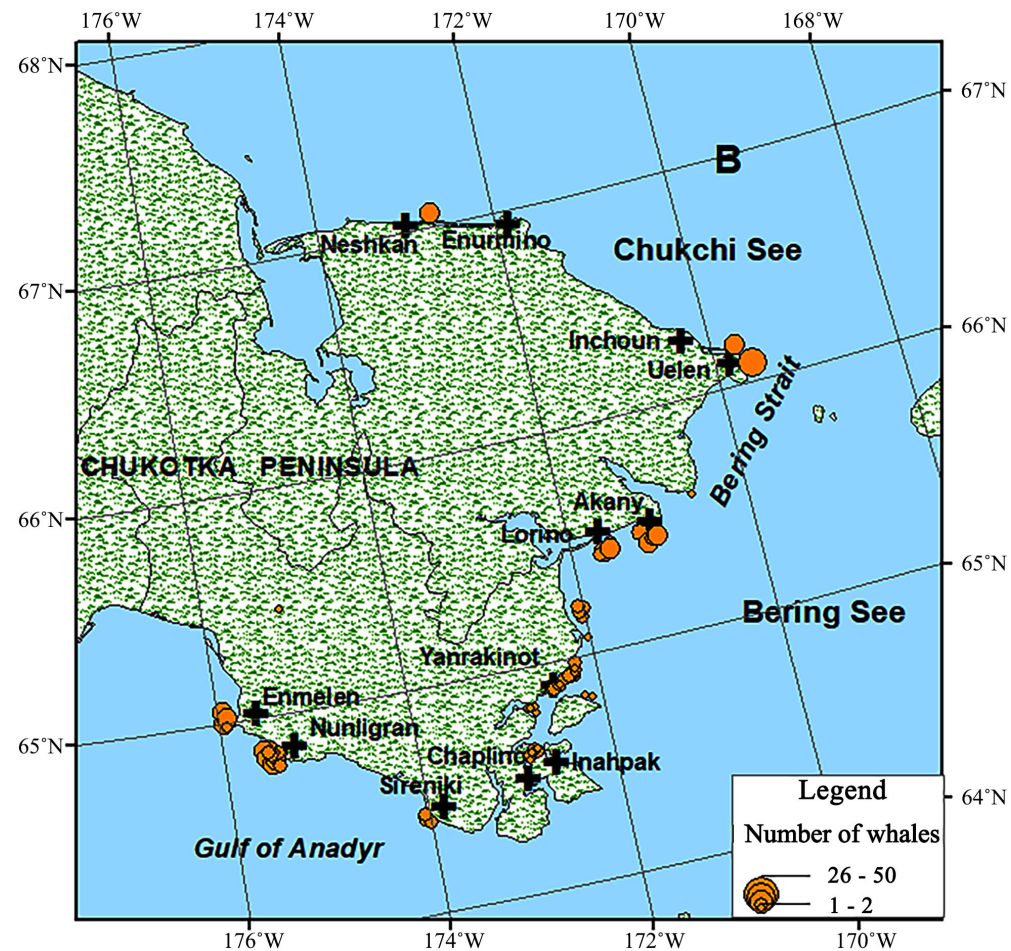

(b)

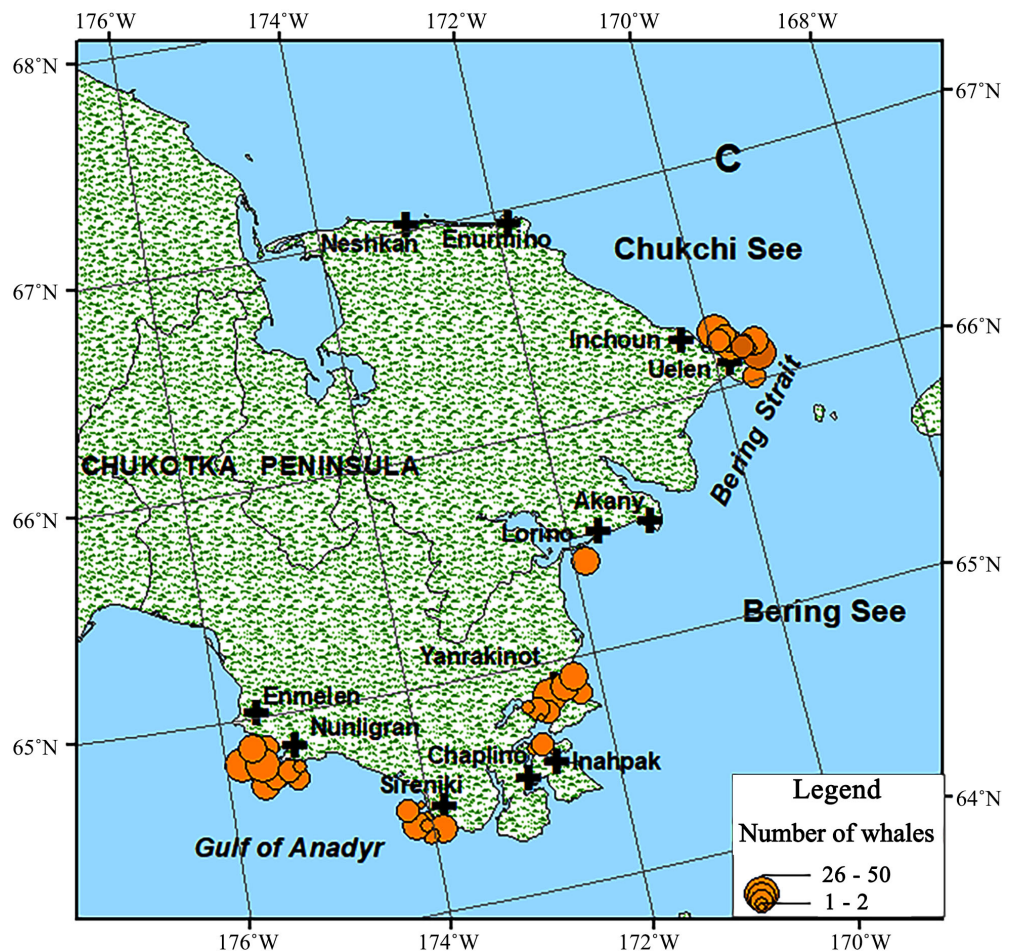

(c)

Figure 8. Interannual distribution of humpback whales in the waters adjacent to the Chukotka Peninsula. (a) Distribution of humpback whales in 1998, a year with a cold summer; (b) Distribution of humpback whales in 2003, a typical year with a high number of observations; (c) Distribution of humpback whales in 2011, a year with the highest number of humpback whales in the waters adjacent to the Chukotka Peninsula. 


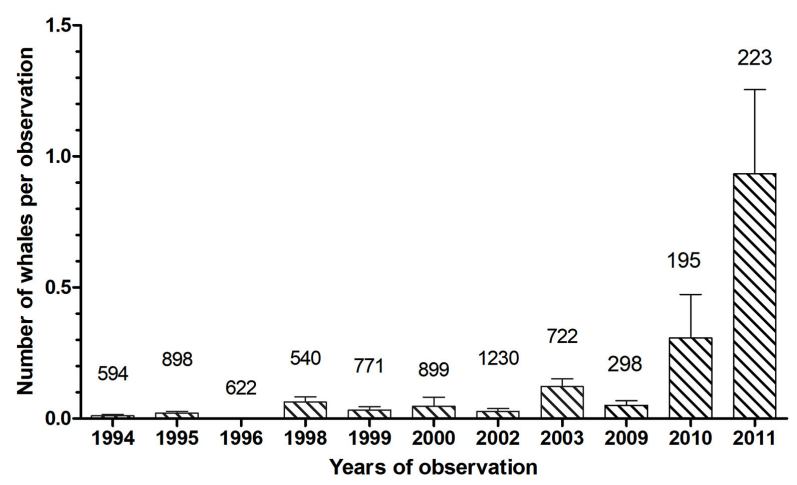

Figure 9. The interannual dynamics of the relative number of humpback whales in the coastal waters of the Gulf of Anadyr. Lines above the columns indicate the standard error and the figures are the number of observations.

As shows Figure 10, in the Bering Sea off the eastern part of Chukotka, as well as in the Gulf of Anadyr, until 2004, the number of humpback whales was fairly stable. The average annual relative abundance index varied from 0.03 in 1998 to 0.17 individuals per observation in 2000. The exception was 1994, when humpback whales were not seen off eastern Chukotka. Figure 8 shows, in 2004 during the second and third ten-day period of October, in the Senyavin Strait, a large number of humpback whales passed, which is reflected in the statistics. In 2010 and 2011 years, there has been a sharp jump in the number of humpback whales, especially in the Senyavin Strait. In 2010, observers counted 0.8 and 2.6 individuals per observation in 2011. Compared with the 1990s and the beginning of 2000, the number of humpback whales off the eastern coast of the Chukotka Peninsula increased by 5 - 15 times.

Figure 11 shows, in the Chukchi Sea, the interannual fluctuations in the relative numbers of humpback whales in the coastal waters off the Chukotka Peninsula have also been extremely high. At the same time, there were two waves that showed an increase in whale numbers. In 1994-1999, the relative number of humpback whales increased from 0.07 to 0.1 individuals per observation. In 2000-2003, the numbers of humpback whales dropped, and on average, 0.03 individuals were noted per observation. In 2010-2012, the relative number of humpback whales again increased sharply up to 1.3 individuals per observation.

\section{Discussion}

The coastal waters off the Chukotka Peninsula pre-World War II were one of the main feeding areas of humpback whales in the North Pacific [1] [2] [4] 1946). Summarizing the distribution of whales in the North Pacific in the postwar period, Arsen'ev [5] stated that in the late 50s - early 60s, humpback whales practically did not meet off the eastern coast of Kamchatka, in the area of the Commander Islands the number of whales decreased significantly. Only in the Gulf of Anadyr, in the Bering Strait and the Chukchi Sea groups of humpback whales were encountered. In 1962, according to the results of two scientific research 


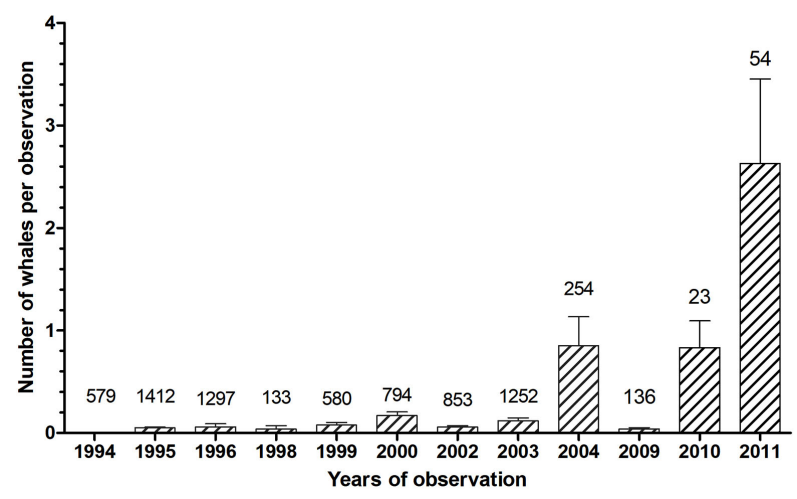

Figure 10. The interannual dynamics of the relative number of humpback whales in the eastern coastal waters off the Chukotka Peninsula. Lines above the columns indicate the standard error and the figures are the number of observations.

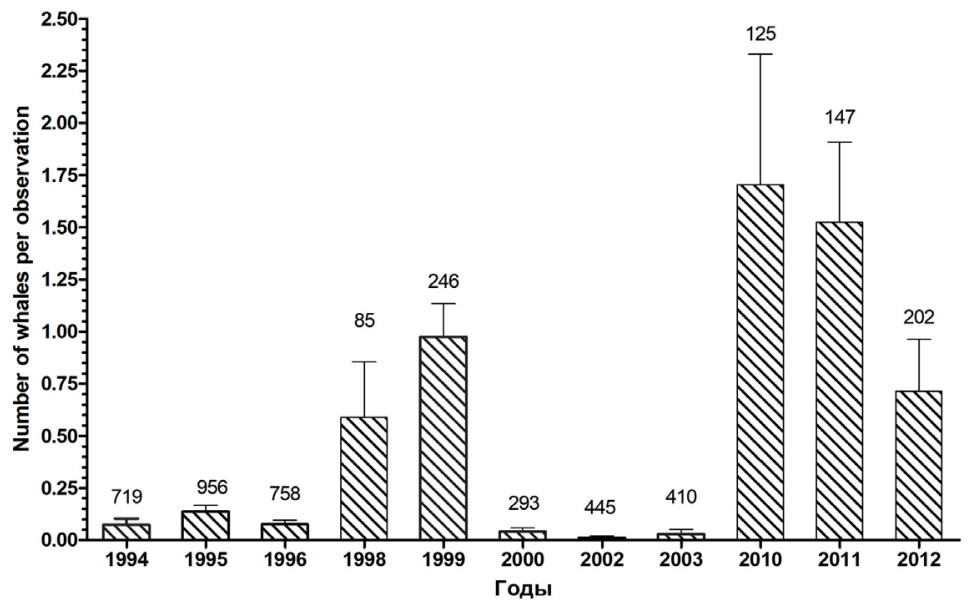

Figure 11. The interannual dynamic index of the relative abundance of humpback whales in the coastal waters of the western part of the Chukchi Sea.

expeditions, it was shown that in the Bering Sea, humpback whales formed aggregations south of Nunivak Island, near Cape Newham, between Pribilof Island and Cape Newham, near Cape Navarin, in the Gulf of Anadyr and slightly to the north of St. Lawrence Island. In the area of the Pribilof Islands, there were diffused packing. Near the Commander and Western Aleutian Islands there were no humpback whales. Single humpback whales were seen at Cape Olyutorsky, in the Olyutorsky Bay, to the west of St. Lawrence Island and in Mechigmen Bay. While advancing search vessels to the east along the chain of the Commander and Aleutian Islands, these humpback whales began to meet on the Pacific side of the Andreanoff Islands [5] [7].

With the closure on commercial whaling, interest in research on large whales, especially on the Russian side, was also lost. There was only scattered information about the encounters of humpback whales in the western Pacific. Most of the information was obtained in passing while doing other work. Thus, during the gray whale whaling for the needs of the Chukotka natives, there were only 68 humpback whales were recorded from the "Zvezdniy" whale-boat for the 10 year 
period from 1969 to 1978 [8]. For a long time, rare scientific research expedition's signs of any humpback presence in the western Pacific are not detected. In October-December 1987, during the expedition to the main whaling areas in the northern part of the Pacific, not a single humpback whale was encountered near Kamchatka, Kuril and Commander Islands [9]. In American literature even expressed the opinion of [10] that the humpback whale population living in the northwestern Pacific Ocean was probably exterminated as a result of unrestrained commercial whaling, and that the majority of these whales, except period of migration, remain in the territorial waters of the United States.

In the early 80 s, humpback whales began to appear on the Russian coast. So, in September 1980, 23 individuals were met at Cape Serdse-Kamen, in the Chukchi Sea [11], in September 1986, a group of 24 humpback whales was recorded in the Gulf of Anadyr [12]. In the late 1980s, these whales began to meet in the area of Olyutorsky Bay [13]. Two animals were met off the Koryak coast, in the area between Cape Olutorsky and Cape Navarin [14]. On the American side, it became common to meet of these animals on the Pacific side of the Alaska Peninsula, where a significant group was annually feeding around Kodiak Island [15]. The largest known group of humpback whales was fed in the south-eastern part of the Gulf of Alaska. Here, humpback whales were found year-round [16]. During the expedition for search of whales on the Bering Slope, humpback whales were found in the Unimak Strait area and on the external border of the Gulf of Anadyr. Data from opportunistic sightings during June July, 1980-99 was shown that humpback whales were found on the outer border of Bristol Bay and Kuskokwim Bay [17].

During surveys of cetaceans in the exclusive economic zone of Russia in July-September 2005, 140 individuals in 66 groups were recorded to the south Commander Islands and northern Kuril Islands [18]. At the Commander Islands humpback whales have begun to be regularly recorded since the 2000s [19]. Last time humpback whales the most abundant species of large cetaceans in the waters of the Commander Islands. In 2010, large feeding aggregations were observed, some comprised of more than hundred animals. Distribution of humpback whales in the area was rather variable; in some periods whales could totally disappear from the area and then came again. Photo identification showed that many humpbacks regularly come to the Commander Islands from year to year, but many others were registered only once. Apparently the waters of the Commander Islands are the main feeding ground for some of the animals and transit region for others [19] [20] [21] [22].

Karaginsky, Olyutorsky and Korfa Gulfs are the historical places of humpback whales aggregation at summer-fall period [23]. Humpback whales were encountered there single or in group of $3-20$ animals. The high number of humpback whales encounter was due to whale concentrations on herring aggregations where extensive fishing surveys were conducted [24]. A growing number of humpback whales found on the proposed route of seasonal migrations of the Asian stock from the southern Japanese islands along the Kuril Islands, eastern 
Kamchatka, the Commander Islands and the Koryak coast. The first evidence of the migration of humpback whales of the Asian stock from the waters of Japan to the northern cape of Karaginsky Island appeared [25]. The migration links between whales feeding in the waters of the Gulf of Anadyr and the whales breeding in the waters of the Raykoku and Ogasawara Islands (Japan) and the Hawaiian Islands are shown. Also shown is the connection of whales feeding near the Commander Islands and Asian, Hawaiian, and Mexican regions [25] [26].

Now, our observations indicate that humpback whales are fairly common in the waters off the Chukotka Peninsula once more. In the summer months, the number of humpback whales is not large. However, by the autumn, their numbers increase, reaching a maximum in the Gulf of Anadyr in October-November and in the northern part of the Bering Sea in September-October. In the Chukchi Sea, the highest numbers of humpback whales were observed from late August to late October. The average values of October, for all the studied years, exceed the average values of August by 5.6 times. This may be because of whale approach to the coast from the open part Chukchi Sea, before migration and the formation of aggregations prior to the start of autumn migration. Also, it may do with some intense seasonal prey availability during the autumn peak regarding the number zooplankton. On 30 August, 2011 groups of humpback whales actively foraging in the giant plankton field in the Longa Strait between Wrangel and Koliuchin Islands [27].

In recent years, our work in the waters of the Chukotka Peninsula has seen a sharp increase in the number of humpback whales; this is especially noticeable in 2010 and 2011. The reason for such a significant increase in the number of humpback whales is not clear yet. It is noteworthy that in the same period the number of humpback whales also sharply increased in the area of the Commander Islands [19] [20], which suggests a possible link between these groups. Obviously, as the number of whales recovers, their former habitat is restored. Humpback whales are reinhabiting their summer grazing grounds in the waters off the Chukotka Peninsula. Currently, these waters are an important grazing site for the humpback whale in the North Pacific.

\section{Summary}

In summary, our sightings show that the humpback whale is reinhabiting its summer grazing grounds in the waters off the Chukotka Peninsula. Humpback whales come to these waters every year. In summer, the number of these whales is consistently low, but in the autumn, the number of humpback whales increases. Currently, these waters are an important grazing ground for the humpback whale in the North Pacific once more. The presence of large feed aggregations shows that water of Chukotka peninsula is a key area for the humpback whales feeding before leaving to winter breeding grounds.

Our data and analysis of the literature indicate that there is a marked increase 
in the number of humpback whales in the North Pacific. Comparing the former and modern feeding area, it can be concluded that the humpbacks now occupy almost the entire range, which they occupied in the North Pacific Ocean before intensive commercial exploitation. The fastest filling of the former feeding area occurred in the Gulf of Alaska, Gulf of Anadyr and the waters around the Chukotka Peninsula. We can assume that the number of recovery of humpback whales feeding on the former fields takes place primarily in the most food-rich areas and does not depend on their distance from places of wintering and breeding.

Humpback whales feeding aggregation off the Chukotka Peninsula creates good conditions for the study of their number and population structure and further monitoring.

\section{Acknowledgements}

The author expresses his gratitude to the administration of the North Slope of the State of Alaska for multiyear support of sea mammal research in the waters off the Chukotka Peninsula, especially Dr Thomas F. Albert, who initiated the joint project. My special gratitude goes out to Mikhail and Gennady Zelensky, Liudmila Ajnana, I. Zagrebin and E. Zdor for organisational help with marine mammal research in Chukotka. The biggest thanks go out to all the hunters who were observing marine mammals; without their help, this work would have been impossible.

\section{Conflicts of Interest}

The author declares no conflicts of interest regarding the publication of this paper.

\section{References}

[1] Tomilin, A.G. (1937) Whales of the Far East. Uchonye zapiski MGU, 13, 119-167.

[2] Nikulin, P.G. (1946) Distribution of Cetaceans in Seas Adjacent to the Chukotka Peninsula. Vol. 22, TINRO, Vladivostok, 255-257.

[3] Sleptsov, M.M. (1961) Fluctuation in Numbers of Whales in the Chukchi Sea in Different Years. Trudy Instituta morfologii zhivotnykh im. A.N. Severtsova, Vol. 34, 54-64.

[4] Vladivasov, M.P. (1946) Whaling in the USSR in the Far East in 1941-1944. Vol. 22, TINRO, Vladivostok, 239-252.

[5] Arsen'ev, V.A. (1961) The Distribution of Whales in the Bering Sea and Possibility for the Development of Whaling. Trudy soveshchaniya po ekologii i promyslu morskikh mlekopitayushchikh, No. 12, 112-124.

[6] Doroshenko, N.V. (2000) Soviet Whaling for Humpback Whales (Megaptera novaeangliae) in the North Pacific. Materialy sovetskogo kitoboynogo promysla (1949-1979). Tsentr Ekologicheskoy Politiki Rossii, Moscow, 48-95.

[7] Berzin, A.A. (2008) The Truth about Soviet Whaling. Marine Fisheries Review, 70, 4-59.

[8] Votrogov, L.M. and Ivashin, M.V. (1980) Sightings of Fin and Humpback Whales in 
the Bering and Chukchi Seas. Report of International Whaling Commission, 30, 247-248.

[9] Berzin, A.A. and Vladimirov, V.A. (1988) Results of Observations on the Distribution and Number of Cetaceans Obtained on the Whaling Ship Dobry in October-December 1987. Nauchno-issledovatel'skiye raboty po morskim mlekopitayushchim severnoy chasti Tikhogo okeana v 1986-1987 gg. VNIRO, Moscow, 11-17.

[10] National Marine Fisheries Service (1991) Final Recovery Plan for the Humpback Whale (Megaptera novaeangliae). The Humpback Whale Recovery Team for the National Marine Fisheries Service, Silver Spring, 105 p.

[11] Doroshenko, N.V. (1981) Brief Summary of Cetacean Research during a Voyage of the Whaling Vessel "Raziashchiy" in the Bering, Chukchi, and East Siberian Seas. Scientific Research Work on Marine Mammals in the North Pacific in 1980-1981. VNIRO, Moscow, 13-16.

[12] Blokhin, S.A. (1988) The Results of the Voyage of the PS "Tungus" on Observation of Cetaceans in the Coastal Waters of the Far Eastern Seas in June-October 1986. Nauchno-issledovatel'skiye raboty po morskim mlekopitayushchim severnoy chasti Tikhogo okeana v 1986-1987 gg. VNIRO, Moscow, 24-37.

[13] Schuntov, V.P. (1993) The Current Distribution of Whales and Dolphins in the Far Eastern Sea and Adjacent Waters of the Pacific Ocean. Zoological Journal, 72, 131-141.

[14] Kalinichenko, V.A. (1990) The Distribution of Cetaceans near the Commander Islands and the North-East of Kamchatka. Morskiye mlekopitayushchiye. Tezisy dokladov 10 vsesoyuznogo soveshchaniya po izucheniyu, okhrane i ratsional'nomu ispol'zovaniyu morskikh mlekopitayushchikh. Svetlogorsk. 129-130.

[15] Waite, J.M., Dahlheim, M.E., Hobbs, R.C., Mizroch, S.A., Ziegesar-Matkin, O.V., Straley, J.M., Herman, L.M. and Jacobson, J. (1999) Evidence of a Feeding Aggregation of Humpback Whales (Megaptera novaeangliae) around Kodiak Island, Alaska. Marine Mammal Science, 15, 210-220. https://doi.org/10.1111/j.1748-7692.1999.tb00792.x

[16] Straley, J.M. (1990) Fall and Winter Occurrence of Humpback Whales (Megaptera nivaeangliae) in Southeastern Alaska. Report of the International Whaling Commission, No. 12, 319-323.

[17] Moore, S.E., Waite, J.M., Mazzuca, L.L. and Hobbs, R.C. (2000) Mysticete Whale Abundance and Observations on Prey Association on the Central Bering Sea Shelf. Journal of Cetacean Research and Management, 2, 227-234.

[18] Kornev, S., Miyashita, T., Saito, T., Hiruda, H. and Gusakov, P. (2006) Results of Survey of Cetaceans in the Northvestern Pacific in 2005. In: Marine Mammals of the Holarctic, Marine Mammal Council, Leningrad, 256-261.

[19] Mamaev, E.G., Fomin, S.V. and Chekalski, E.I. (2010) Results of Observation on Cetaceans off Commander Islands in Autumn-Winter-Spring Period. In: Marine Mammals of the Holarctic, Collection of Scientific Papers after the Sixth International Conference, Terra Baltica, Kaliningrad, 362-366.

[20] Belonovich, O.A., Mamaev, E.G., Fomin, S.V. and Konovalova, L.I. (2012) Cetaceans off the Northern Cape of Bering Island, Commander Island. In: Marine Mammals of the Holarctic, Collection of Scientific Papers, Marine Mammal Council, Suzdal, 91-94.

[21] Fedutin, I.D., Filatova, O.A., Burdin, A.M. and Hoyt, E. (2015) Cetaceans in the Waters of the Commander Islands. In: Marine Mammals of the Holarctic, Collection of Scientific Papers after the Eight International Conference, Marine Mammal 
Council, St. Petersburg, Vol. 2, 256-259.

[22] Titova, O.V., Filatova, O.A., Fedutin, I.D., Burdin, A.M. and Hoyt, E. (2015) Feeding Aggregation of Humpback Whales (Megaptera novaeangliae) off the Commanger Islands. In: Marine Mammals of the Holarctic, Collection of Scientific Papers, Marine Mammal Council, St. Petersburg, Vol. 2, 205-208.

[23] Zenkovich, B.A. (1936) Observations on the Whales of the Far Eastern Seas. Trudy DaP nevostochnogo filiala Akademiya Nauk SSSR, 1, 5-59. https://doi.org/10.2307/3022671

[24] Fomin, S.V. and Burkanov, V.N. (2012) Marine Mammal Sightings in Eastern Kamchatka and Western Bering Sea in October-December, 2011. In: Marine Mammals of Holarctic, Collection of Scientific Papers, RPO Marine Mammal Council, Moscow, Vol. 2, 330-335.

[25] Burdin, A.M. and Yamaguchi, M. (2004) Where Are the Feeding Grounds of the Western Population of Humpback Whales (Megaptera novaeangliae)? First Evidence of Migration to Kamchatka. In: Marine Mammals of Holarctic, Collection of Scientific Papers, KMK, Moscow, 101-102.

[26] Titova, O.V., Filatova, O.A., Fedutin, I.D., Ovsyanikova, E.N., Okabe, H., Kobayashi N., Acebes, J.M.V., Burdin, A.M. and Hoyt, E. (2017) Photo-Identification Matches of Humpback Whales (Megaptera novaeangliae) from Feeding Areas in Russian Far East Seas and Breeding Grounds in the North Pacific. Marine Mammal Science, 34, 100-112. https://doi.org/10.1111/mms.12444

[27] Sevostianov, V.E. (2012) Results of Vessel-Based Observations of Marine Mammals in the Russian Arctic Seas and in the Bering Sea. In: Marine Mammals of the Holarctic, Collection of Scientific Papers, Marine Mammal Council, Suzdal, Vol. 2, 222-224. 